\title{
THE CENTRAL SANCTUARY: WHERE AND WHEN?
}

\author{
Jeffrey Niehaus
}

\section{Introduction}

For nearly two hundred years, scholars have given serious attention to the question of the central sanctuary as it appears in Deuteronomy and the Old Testament historical books. Deuteronomy 12:5 calls for Israel 'to seek the place the Lord your God will choose from among all your tribes to put his Name there for his dwelling', and there to worship him and present sacrifices. Traditionally it has been believed that this meant first, the tabernacle (wherever it might be pitched) and then, later, the Solomonic Temple.

Ever since de Wette's Dissertatio Critica of 1805, however, the prospect has been raised that this call was really uttered, not by Moses, but by a later writer, who came to be called the Deuteronomist. ${ }^{2}$ Scholars have variously understood this term to mean the final editor or redactor of Deuteronomy, ${ }^{3}$ or the editor/compiler/redactor of the vast corpus, Deuteronomy-2 Kings. ${ }^{4}$ Driver, for instance, believed

${ }^{1}$ This paper was delivered as the Tyndale Old Testament Lecture 1991.

${ }^{2}$ W.M.L. de Wette, Dissertatio critica qua Deuteronomium a prioribus Pentateuchi libris diversum alius cuiusdam recentioris opus esse monstratur (Jena, 1805). De Wette's theory has found support in its original form well into this century; $c f$. Walther Baumgartner, 'Der Kampf um das Deuteronomium', Theologische Rundschau 1 (1929) 725.

${ }^{3}$ E.g., A. Harper, The Book of Deuteronomy (New York, A.C. Armstrong \& Son 1903).

${ }^{4} \mathrm{M}$. Noth, Überlieferungsgeschichtliche Studien (Halle, M. Niemeyer 1943, 19572) ET. D.R. Ap-Thomas et al., The Deuteronomistic History (Sheffield, JSOT 1981). Noth's work gave this hypothesis its classic formulation. His influence is widely reflected, e.g. I. Engnell, Gamla Testamentet en traditionshistorisk inledning I (Stockholm, Svenska Kyrkans Diakonistyrelses Bokforlag 1945); G.E. Wright, 'The Book of Deuteronomy', in IB 2 (New York, Abingdon-Cokesbury 1953); E.W. Nicholson, Deuteronomy and Tradition (Philadelphia, Fortress 1967); Pierre Buis, Le Deutéronome (Paris, Beauchesne 1969). 
of Deuteronomy 12:5 that 'Of course, the place tacitly designated by the expression is Jerusalem, which is described similarly in passages of Kings due to the Deuteronomy compiler'.5 Von Rad likewise states that 'The phrase so frequently repeated in this connexion about the "place which Yahweh will chose to put his name there" must be claimed as specifically Deuteronomic'.6 Mayes also believes that the phrase itself is a 'deuteronomistic form' which 'finds parallels in the deuteronomistic history'. ${ }^{7}$

On the other hand, J.A. Thompson, after a useful survey of possibilities, has argued the more traditional view that

There was a central sanctuary in Moses' day in the first half of the thirteenth century BC. It can be identified clearly at Shiloh in the eleventh century $B C$, and it became permanent at Jerusalem from the tenth century $\mathrm{BC}$ onwards. The part it was intended to play in Israel's national and religious life is set out in Deuteronomy. 8

Likewise, Craigie has taken the phraseology of Deuteronomy 12:5 to mean that

The place [which Yahweh would choose] would be identified by the tabernacle and the ark within it. . Thus, though there was only one tabernacle, it would be moved from place to place; there would be many places over the course of time, but only one place at a time. 9

K.A. Kitchen had already argued that the place initially intended was the tabernacle, wherever it might stand at a given period. 10

Which of these approaches is correct? What should our understanding be of this command in Deuteronomy, and its application in the historical books of the Old Testament? We will argue that the Old Testament record is sufficiently clear and consistent on this score to warrant acceptance, and that the traditional view adopted by Thompson, Craigie, Kitchen

5S.R. Driver, Deuteronomy (Edinburgh, T. \& T. Clark 19013) 140.

${ }^{6} \mathrm{G}$. von Rad, Deuteronomy (Philadelphia, Westminster 1966) 90.

${ }^{7}$ A.D.H. Mayes, Deuteronomy (London, Marshall, Morgan \& Scott 1979) $223 \mathrm{ff}$.

8J.A. Thompson, Deuteronomy (Leicester, IVP 1974) 41-2; cf. his extended discussion, 35-42.

9P.C. Craigie, The Book of Deuteronomy (Grand Rapids, Eerdmans 1976) 217.

${ }^{10}$ K.A. Kitchen, TSF Bulletin 64 (1972) 9-10n. 
and others, has evidence from the Ancient Near East to support it.

The first step in our task is to examine the biblical record. This record presents a consistent picture of the movement of the tabernacle, from its wanderings in the wilderness to its placement at Jerusalem in Solomon's day. It likewise presents a clear picture of the movement of the ark, from its presence in the tabernacle to its capture by the Philistines, its return to Israel, and its deposition in Abinadab's house until David removed it to Jerusalem and Solomon installed it in the newly completed temple. Central to this review will be a survey of the Old Testament usage of the 'Name' phraseology of Deuteronomy 12:5, which is so intimately associated with 'the place which Yahweh will choose from among your tribes'. Related to this study will be a survey of the usage of the terms for various sacrifices and offerings employed in Deuteronomy 12:5ff and related passages, and a survey of the term, 'high place' (cf. Dt. 12:2), as they occur in the historical books, with special attention to the period before the Solomonic temple.

\section{The Biblical Record}

Our first task is to review the Old Testament usage of the 'Name' phraseology. The relevant texts are in Deuteronomy and 1 and 2 Kings.

The phrase first occurs in Deuteronomy 12:5.11 After a command to destroy the altars, sacred stones, and Asherah poles at the high places in Canaan, Moses tells the people that they must not worship the Lord in the way of the Canaanites, 'But you are to seek the place the Lord your God will choose from all your tribes to put his Name there for his dwelling' (Dt. 12:5)

${ }^{11} \mathrm{G}$. Minette de Tillesse, 'Sections "Tu" et Sections "Vous" dans le Deuteronome', VT 12 (1962) 29-87, has argued that this verse, which addresses Israel in the plural, is later than v. 14, where the formula appears with Israel addressed in the singular. The later verse reflects the Deuteronomist, who uses similar phrasing in $2 \mathrm{Ki} .11: 36,14: 21 ; 2 \mathrm{Ki}$. 21:7. The error of using the singular/plural shift as a criterion for distinguishing authorship has already been sufficiently indicated by $\mathrm{K}$. Baltzer, Das Bundesformular (Neukirchen, Neukirchener Verlag 1960), and W.L. Moran, 'Klaus Baltzer, Das Bundesformular', Biblica 43 (1962). 
In the repetitive style which he uses for rhetorical emphasis, Moses further encourages the people to bring their offerings to 'the place the Lord your God will choose as a dwelling for his Name' (12:11) once they have conquered, and the Lord has given them rest from their enemies in the promised land.

Because every slaughtering of an animal could be termed a sacrifice, a distinction has to be made between that which might be done at home, and that which must be done at the 'chosen place'. Provision is made, therefore, for what has been called the 'secular' slaughter of animals as well: 12

If the place where the Lord your God chooses to put his Name is too far away from you, you may slaughter the animals from the herds and flocks the Lord has given you, and in your own towns you may eat as much of them as you want (Dt. 12:21; cf. 15).

A similar provision is made for the offering of tithes in Deuteronomy 14:23-24:

If the chosen place is too far for them to bring their tithe, they shall turn it into money, go to the chosen place, and re-convert the money into 'whatever your appetite craves; and you shall eat there before the Lord your God and rejoice, you and your household.

Firstlings also are to be eaten in the presence of the Lord your God at the place he will choose' (Dt. 15:20).

In addition, the Passover of the Lord must be celebrated 'in the place he will choose as a dwelling for his Name' (Dt. 16:6, cf. 2). Likewise, the Feast of Weeks must be held there (Dt. 16:11), and the Feasts of Unleavened Bread and Tabernacles (Dt. 16:16).

Finally, once the people have entered the land, and have taken possession and settled in it, they are to take some of the firstfruits of all they produce in a basket 'to the place the Lord your God will choose as a dwelling for his Name'. They must present it to the priest then officiating, and affirm, 'I declare today to the Lord your God that I have come to the land the Lord swore to our forefathers to give us' (Dt. 26:3). As Craigie observes, this declaration 'did not only reflect man's experience; it was a testimony also to the faithfulness of God,

12Mayes, op. cit., 225. 
who had promised the land long ago and had now fulfilled that ancient promise by giving the land to his people' 13

It appears that all of these passages refer to the same 'chosen place'.14 Welch, however, has argued that only the Deuteronomy 12:5 passage necessitates that interpretation. He has successfully shown that although the other passages may be taken in the sense of one exclusive place, they need not be.15 From this, however, he concludes that Deuteronomy 12:1-7 is a later interpolation in the book. However, since Welch himself admits that the other passages in Deuteronomy may be interpreted in the sense of one exclusive place, these passages may and indeed should be considered compatible with Deuteronomy 12:5, as more recent scholars have affirmed.16

The point that Welch and others have missed is, that there would be only one 'chosen place'-namely, the location of the tabernacle-but that this place might change from time to time. The reason they have missed this point is, that they have assumed from the outset that the 'chosen place' of

${ }^{13}$ Craigie, op. cit., 320.

${ }^{14}$ So also G.J. Wenham, 'Deuteronomy and the Central Sanctuary', Tyn B 22 (1971) 103-118 (esp. 110-112). Incidentally, the passages demonstrate variety in phrasing which is just like that found in stock phrases in Assyrian royal inscriptions; $c f$. R. Borger, Einleitung in die Assyrischen Königsinschriften (Leiden, Brill 1961), and W. Schramm, Einleitung in die Assyrischen Königsinschriften 2 (Leiden, Brill 1973), passim. It is quite unnecessary, therefore, to suppose that Dt. 12:5, which uses both the verb, שום, and the verb, formulas in Dt. (e.g., Dt. 12:21, 14:24, which use the verb, 口iש; 14:23, $16: 2,6,11 ; 26: 2$, which use the verb, 10 (j) - that it 'conflates the vocabulary' of such and is therefore 'no earlier in origin', as B. Halpern, 'The Centralization Formula in Deuteronomy', VT 31 (1981) 20-38 (esp. 23-24ff), has argued.

15A.C. Welch, 'The Problem of Deuteronomy', JBL 48 (1929) 291-306. Cf. his earlier 'When was the worship of Israel centralized at the temple?', ZAW 2 (1925) 250-5; The Code of Deuteronomy (London, James Clarke \& Co 1924). Welch was preceded in this line of argument by Theodore Oestreicher, Das Deuteronomische Grundgesetz (Gütersloh, 1923) and W. Stärk, Das Problem des Deuteronomiums (Gütersloh, 1924). Cf. F. Dumermuth, 'Zur deuteronomischen Kulttheologie und ihren Voraussetzungen', ZAW 70 (1958) 59-97 (esp. 61).

${ }^{16} \mathrm{Cf}$. Dumermuth, op. cit., 61; E. Nicholson, 'The Centralisation of the Cult in Deuteronomy', VT 13 (1963) 380-9; A. Phillips, Deuteronomy (Cambridge University Press 1973) 84-5. 
Deuteronomy 12:5 is the Jerusalem temple.17 This is an old assumption, stemming from the work of de Wette, and it is still current. 18 But it is only an assumption. ${ }^{19}$ We will examine phraseological evidence from the Ancient Near East which points toward a different conclusion.

Another question that has been raised regarding the legislation of Deuteronomy 12:5 is whether it bans all sacrifices other than those at the chosen place. For if it does not, the door is obviously open to the legitimacy of other sacrifices elsewhere, under certain conditions, perfectly consistent with the Deuteronomic legislation. In answer to this question, Keil and Delitzsch declare that,

As God of the whole earth, wherever it might be necessary, for the preservation and promotion of His kingdom, He could make known His presence, and accept the sacrifices of His people in other places, independently of this sanctuary; and there were times when this was really done. 20

On the other hand, Welch believes that 'To this shrine Israel must bring [all of her offerings]. Nothing is excluded'. ${ }^{21}$ But the language of Deuteronomy 12:5 need not be pressed so far. The command says that they must bring 'your burnt offerings and sacrifices, your tithes and special gifts, what you have vowed to give and your freewill offerings, and the firstborn of your herds and flocks'. The list may sound exhaustive, but it is not. As Mayes notes, 'the list of offerings and sacrifices, apparently intended to be comprehensive, makes no reference to the sin and guilt offerings (Lv. 4:1ff)'.22 The list is a general

${ }^{17}$ Welch, op. cit., 292, declares of the phrase, 'It means the temple at Jerusalem'.

18E.g., M. Noth, 'Jerusalem und die israelitische Tradition', Oudtestamentische Studien 8 (1950) 46; V. Maag, 'Erwägungen zur deuteronomischen Kultzentralisation', VT 6 (1956) 10-18; R.E. Clements, 'Deuteronomy and the Jerusalem Cult Tradition', VT 15 (1965) 300-12; Mayes, op. cit., 223; N. Lohfink, 'Zur deuteronomischen Zentralisations-formel', Biblica 65 (1984) 297-329 (esp. 297).

${ }^{19}$ Even von Rad, op. cit., 94, argues that the assumption that Jerusalem was the place intended by the deuteronomic law 'was probably too hasty' and that 'the question is still wide open'.

${ }^{20}$ C.F. Keil and F. Delitzsch, Commentary on the Old Testament, III, E.T. James Martin (Grand Rapids, Eerdmans 1976) 335.

${ }^{21}$ Welch, Code, 58-59.

22Mayes, op. cit., 226. 
one, and given for emphasis, not for exclusivity. The statement may be taken as an example of Ancient Near Eastern hyperbole-never meant to be taken quite literally, always meant to emphasize a point. Examples abound-for instance, the boast of Rameses II that he destroyed all the allied chiefs arrayed against him at the battle of Kadesh, which is soon followed by a comment that one of them was receiving artificial respiration after crossing the Orontes! 23 Indeed, an example of hyperbole occurs only three verses before, in Deuteronomy 12:2, where Israel is commanded to destroy the Canaanite places of worship 'under every spreading tree'. We know this is not to be taken literally. ${ }^{24}$ The legislation which follows in Deuteronomy 14 and 16 makes it clear that what is especially mandated by Deuteronomy 12:5 is the bringing of tithes (cf. Dt. 12:17), observance of the Passover and the Feasts of Weeks and Tabernacles, as well as other sacrifices. Not necessarily included are covenant renewal ceremonies (e.g., Jos. 8:30-35, the covenant renewal at Mts Gerizim and Ebal, mandated in Dt. 27:2ff) 25 or occasional sacrifices, such as some burnt offerings and peace offerings (e.g., Jdg. 21:4; 1 Sa. 11:15). This latter exception, which we see practised during the period of the judges and the early monarchy, is entirely consistent with the provision in Exodus 20:24-25 that they shall make make an altar of earth or unhewn stones in every place where I cause my Name to be remembered', to sacrifice their burnt offerings and their peace offerings. ${ }^{26}$ As we shall see, this

${ }^{23} \mathrm{~J} . \mathrm{H}$. Breasted, Ancient Records of Egypt III (Chicago, University of Chicago 1906) 151-4.

${ }^{24}$ There were presumably 'spreading trees' which did not shelter Canaanite places of worship! There are other examples of hyperbolic language in Dt.: 1:11 (cf. 10:22; 28:62), 1:28 (cf. 9:1), 4:32 (cf. 13:8; 28:64; $30: 4), 6: 3$ (cf. 11:9; 26:9,15; 27:3; 31:20), and probably also 6:7-8 (cf. 11:1819).

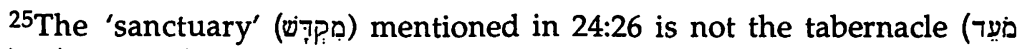
inik), as Keil and Delitzsch, op. cit., II, 233, note, but 'the holy place under the oak, where Abraham had formerly built an altar and worshipped the Lord, and where Jacob had purified his house from the strange gods, which he buried under this oak, or rather terebinth tree'. Cf. Gn. 12:6-7, 35:2-4.

26M. Kline, Treaty of the Great King (Grand Rapids, Eerdmans 1963) 812, notes here an essential connection between altars and theophanies: 'Significant changes in the nature of theophany from era to era 
provision has in view especially occasions of battle or theophany-special circumstances which, in the nature of the case, would virtually preclude involvement of the central sanctuary. We suggest, then, that occasional sacrifice at places other than the 'chosen place', as recorded with approval in the historical books, is also permitted by Deuteronomy 12:5.27

A survey of the terms, 'holocaust' (עולה), 'sacrifice' (זבח), 'altar' (מבזה), and 'high place' (במה), chiefly in contexts of Yahweh worship, is consistent with this view.

The term, 'holocaust' (עולה), for instance, is used in several distinct contexts. The term is used for various special circumstances, e.g., the Mt. Ebal-Mt. Gerizim covenant renewal (Jos. 8:31). It also appears in sacrifices for special occasions which Yahweh/the angel of Yahweh commands or approves, e.g., Judges 6:26 (Gideon), Judges 13:16,23 (Manoah), or when God works judgment or gives victory (e.g., Judg. 20:26, 21:4), or upon return of the ark from the Philistines (1 Sa. 6:14,15) or Samuel's command to Saul (1 Sa. 10:8); or in an appeal for victory, such as Samuel makes at Mizpah (1Sa. $7: 9,10)$. One one special occasion, David brings the ark from Obed Edom's house to the tent in Jerusalem (2 Sa. 6:17,18); and on yet another, David, at Yahweh's word (through Gad the seer), offers sacrifices on the threshing floor of Araunah the Jebusite, the future sight of the temple (2 Sa. 24:22,24,25). Other uses include clearly illegitimate sacrifices, such as Jephthah's sacrifice of his daughter (1 Sa. 13:9,10,12). The term also appears for sacrifices at the central sanctuary (e.g., $1 \mathrm{Ki}$. $8: 64,9: 25)$. For Solomon's sacrifices at the high places (1 Ki. 3:4, 2Ch. 1:3-6), see below.

required corresponding changes with respect to the altar. Thus, during the days of the patriarchs altars were frequently erected at the various sites where God appeared, but there was not a continuing central altar until there was a continuing revelation of the presence of God in the form of the Shekinah glory tabernacling in the midst of Israel. This form of theophany began in the Mosaic era and the covenant stipulations given at Sinai, though they did not exclude altars at other places where God might record his name, were concerned primarily with the continuing central or official altar which would be associated with this abiding Shekinah theophany.'

${ }^{27}$ So also Wenham, op. cit., 110; J. Ridderbos, Deuteronomy (Grand Rapids, Zondervan 1984) 151-3; J.C. Maxwell, Deuteronomy (Waco, Word 1984) 183ff. 
A similar picture appears when we consider the usage of the term, 'sacrifice' (זבח).28 Here again, Yahweh sacrifices from Joshua's day through the period of the judges and early monarchy appear limited to a few distinct categories. Brief mention is made of pagan sacrifices (Philistines to Dagon, Jdg. 16:23). There are sacrifices for special occasions, e.g., Joshua's covenant renewal at Mts. Ebal and Gerizim (Jos. 8:31, already commanded in Dt.); or, when Yahweh communicates judgment or gives victory, e.g., at Bochim (Jdg. 2:5), or upon return of the ark from the Philistines (1 Sa. 6:15); or Samuel's instruction to Saul at Gilgal (1 Sa. 10:8), or his reaffirmation of Saul's kingship at Gilgal (1 Sa. 11:15); or later, when David brings the ark from Obed Edom's house to the tent that he has prepared for it in Jerusalem (2 Sa. 6:13). Other uses include clearly illegitimate sacrifices, such as Adonijah's sacrifice, which is part of a conspiracy $(1 \mathrm{Ki} .1: 9,19,25)$; also the tampering with the sacrifices by Eli's sons at Shiloh (1 Sa. 2:13,15). Saul's sacrifice at Gilgal was also clearly sin (1 Sa. 15:15,21). We consider the case of Absalom as illegitimate (2 Sa. 15:12) because his vow was a ruse. There were also legitimate sacrifices at the central sanctuary, both at Shiloh (Elkanah, 1 Sa. $1: 3,4,21 ; 2: 19$ ), and at the Jerusalem temple (e.g., $1 \mathrm{Ki}$. $8: 62,63 ; 12: 27)$. For Solomon's sacrifices at the high places (1 Ki. 3:2,3), see below. The witch of Endor's 'sacrifice' (1 Sa. 28:24) is apparently made only to feed Saul. In 1 Samuel 16:2,5, Yahweh commands Samuel to make a sacrifice and anoint a new king to replace Saul. Like the annual sacrifice for his clan mentioned by David (1 Sa. 20:6, cf. 29), this, too, is obviously a special case-one of the 'other festal sacrifices not defined in the codes of law' $(B D B, 257)$.

In other words, the use of the terms, עולה and זבח, shows that it was mainly for unusual occasions-some of them commanded by Yahweh or his angel, some of them in war contexts where the Lord is active-that Yahweh sacrifices were made apart from the 'chosen place'. Such sacrifices were made, in the language of the provision in Exodus 20:24-25, 'in every place where I cause my Name to be remembered'. This is

${ }^{28}$ The verb. Occurrences of the noun are essentially the same (Jdg. 16:23; 1 Sa. 1:21; 2:13,19,29; 3:14; 6:15; 9:12,13; 10:8; 11:15; 15:22,22; 16:3,5,5; 20:6,29; 1 Ki. 8:62,63; 12:27). 
just what one would expect, and is hardly precluded by Deuteronomy 12:5.

Incidentally, the same varieties of usage occur during the period of the Solomonic temple. For example, ז is used of sacrifice to idols ( $1 \mathrm{Ki} .11: 8,12: 32)$, legitimate worship at the 'chosen place' (1 Ki. 8:5.62.63), and of illegitimate worship at the 'high places' (1 Ki. 22:43; 2 Ki. 12:3, 14:4, 15:4.35, 16:4). A special case, not at the temple, may be Elisha's 'sacrifice' of his oxen before he leaves home to follow Elijah (1 Ki. 19:21), but this is perhaps only a 'slaughter' after all. The term עולה, likewise, is used of legitimate worship at the 'chosen place' (1 Ki. 8:64, 9:25, 10:5; 2 Ki. 5:17), and of illegitimate worship (2 Ki. 16:13.15), as well as pagan sacrifice (2 Ki. 3:27; cf. $2 \mathrm{Ki} .10: 24.25$, Jehu at Baal's temple in Samaria). It is also used of Yahweh's judgment intervention on Mt Carmel (1 Ki. 18:33,38). The Carmel event clearly shows that Yahweh can approve a sacrifice not offered at the 'chosen place', and that in a most dramatic way, when it is offered in a special context and for a special purpose. This, also, is not precluded by Deuteronomy 12:5.

The use of the term, 'altar' (מזבח), is also consistent with what we have seen for the terms עולה (מבח Mention is made of pagan altars, both in the general command to destroy them (Jdg. 2:2), and in the context of apostasy (Joash's Baal altar, 6:25.28.30.31; the golden calf altar at Bethel, $1 \mathrm{Ki}$. 12:32.33, 13:1ff; Ahab's altar in the Baal temple at Samaria, 16:32ff; the Baal altar on Mt Carmel, 18:26). Many altars are mentioned in connection with special circumstances: e.g., the altar for covenant renewal at Mt Ebal (Jos. 8:30.31); the memorial altar at Gilead (Jos. 22:10ff); Gideon's altar occasioned by theophany (Jdg. 6:24.26.28); Manoah's similar altar (Jdg. 13:20); Israel's (memorial?) altar at Mizpah (Jdg. 21:4); and Saul's altar after the victory at Michmash (1 Sa. 14:35). It has been suggested that Samuel's altar at Ramah (1 Sa. 7:17) was a provisional substitute for the tabernacle altar, since during his judgeship the tabernacle was at Shiloh (cf. 1 Sa. 2:28.33), but the ark of the covenant was at Abinadab's house in Kiriath-Jearim.29 The nature of Samuel's altar is unclear. There is no need to think of it as anything other than an altar after the pattern of Exodus 20:24-25, not at all intended for the sacrifices which Deuteronomy assigns to the

${ }^{29}$ Cf. C.F. Keil \& F. Delitzsch, op. cit., II, 77. 
'chosen place'. Solomon's sacrifices at the high place at Gibeon (1 Ki. 3:4) were certainly provisional: the ark was at KiriathJearim, while the tabernacle was at Gibeon ( $2 \mathrm{Ch}$. 1:3-6). Of course, some of the altars Solomon built were in violation of the law: namely, the altars at the high places east of Jerusalem for the worship of pagan deities-Ashtoreth, Chemosh, and Milcom (2 Ki. 23:13). Josiah defiled these sites once Shaphan had read the 'Book of the Law' to him (2 Ki. 22:10). Other illegitimate altars are mentioned in Hezekiah's reign $(2 \mathrm{Ch}$. 30:14). The Yahweh altar to which Adonijah and Joab cling (1 Ki. 1:50.51.53, 2:28.29) is presumably the altar in the Davidic tent in Jerusalem.30 Again, mention is made of the central sanctuary altar, both early (the Gibeonites to supply it, Jos 9:27), and later (the Solomonic temple, 1 Ki. 6:20,22; 7:48; 8:22ff; 9:25). The identity of the Yahweh altars mentioned by Elijah ( 1 Ki. 19:10), after his own special altar to Yahweh (1 Ki. $18: 30,32,35)$ had served its purpose, is unclear. They may have included the various memorial altars and altars for special occasions noted above.

Other passages in Deuteronomy also include terms for sacrifice or offering relevant to Deuteronomy 12:5. Deuteronomy 12:6 includes several such. The terms and their occurrence are as follows. 'Tithe' (מֵעֵשֶ) does not occur in Joshua-2 Kings. It appears in 1 Chronicles 31:5,6,12, in the context of Hezekiah's care for the Jerusalem temple. 'Special gifts' (תָּרוּמָ) occurs in 2 Samuel 1:21 (David at the Jerusalem tent upon deposition of the ark), and 2 Chronicles 31:10,12,14 (Hezekiah at the Jerusalem temple). 'Vow' (נרךר) occurs at Judges 11:30,39 of Jephthah's vow, and at 1 Samuel 1:11 (Hannah's vow) and 1 Samuel 1:21 (Elkanah's vow), and at 2 Samuel 15:7,8 (Absalom's purported 'vow'). 'Freewill offering' (נירדבָה does not occur in Joshua-2 Kings, but at 2 Chronicles 31:14 of Hezekiah's care of the temple, and 2 Chronicles 35:8

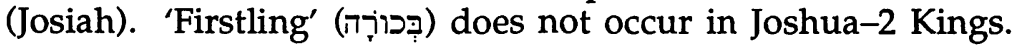
The other relevant terms occur later in Deuteronomy. 'Passover' (חסֶ๊ Dt. 16:1) occurs at Joshua 5:10,11 of Joshua at the tabernacle at Gilgal, at 2 Kings 23:21,22,23 of Josiah at Jerusalem, and at 2 Chronicles 31:1,2,5,15,17,18 of Hezekiah at

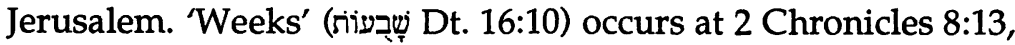
of Solomon at the Jerusalem temple. 'Tabernacles' (rijo, Dt. 16:13) occurs likewise of Solomon (2 Ch. 8:13). 'Unleavened

${ }^{30}$ Cf. idem, op. cit., III, 21. 
bread' (מָָּ Dt. 16:16) occurs of Joshua at the tabernacle at Gilgal at Joshua 5:11, of Solomon at the Jerusalem temple at 2 Chronicles 8:13, of Hezekiah likewise at 2 Chronicles 30:13.21, and of Josiah likewise at 2 Chronicles 35:17. These terms do not appear in the pre-exilic prophetic literature. The relevance of this data will be made clear below.

A survey of 'high place' (במה), shows a somewhat different pattern from what we have so far observed. The term is used of pagan sites: e.g., Solomon's high places for Chemosh and Molech (1 Ki. 11:7); Jeroboam I's high places (1 Ki. 12:31,32; 13:2,32,33). It is also used of high places in Judah generally (1 Ki. 14:23), and during the reigns of Asa (1 Ki. 15:14) and Jehoshaphat (1 Ki. 22:43). These high places were clearly outlawed without exception by Deuteronomy. Such was not the case for the sacrifices, feasts and altars that we have surveyed. Exceptions seem to have been made: for Samuel eats a sacrifice with Saul at a high place (1 Sa. $9: 12,13,14,19,25)$, and the prophets descend to meet Saul from a high place (1 Sa. 10:5,13), and neither of these cases receives rebuke from any deuteronomistic redactor of 1 Samuel. There is no censure of the high places until Solomon's reign, because it was not until then that, after at least 70 years, worship might again be offered at a central sanctuary which also contained the ark. The high places were outlawed in Deuteronomy because they were the site of pagan worship. If Israel worshipped on these sites-even if they worshipped Yahweh there, after destroying pagan altars - they might yet be open to syncretistic influences, and could be seduced into the worship of the deities originally worshipped at those high places. This is what happened. Some of the worship at these places involved pagan gods, some of it involved Yahweh, but all of it is censured in the books of Kings. 31 Deuteronomy 12:2-4 anticipates just such a danger. The real thrust of that chapter is not so much to centralize worship as it is to eliminate idolatry and guard against syncretism. ${ }^{32}$

${ }^{31}$ As Keil \& Delitzsch, op. cit., III, 218-9, rightly argue, the high places for which even good king Asa receives censure are not 'high places dedicated to idols, but unlawful altars to Jehovah'. The same is true of 1 Ki. 22:24; 2 Ki. 12:4, 14:4, 15:4; 2 Ch. 15:17, $20: 33$.

${ }^{32}$ Cf. A. Harper, op. cit., 260; Welch, Code, 198ff; Gressmann, as cited in Welch, Problem', 301-2; Phillips, op. cit., 85; Ridderbos, op. cit., 153. 
What, then, does our survey indicate? Firstly, there is no evidence in the historical books or the prophets that any of the national festivals assigned by Deuteronomy to the 'chosen place' (i.e., the location of the tabernacle/temple) were sacrificed anywhere else until Jeroboam instituted an alternative Feast of Tabernacles at Bethel, 'like the festival held in Judah', involving sacrifice to 'the calves he had made' (1 Ki. 12:32).33 Our survey of 'Passover' (กסํㅛ, Dt. 16:1), 'Weeks'

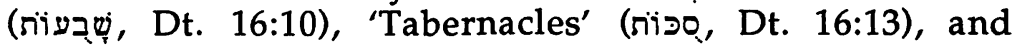
'Unleavened bread' (מָָָ Dt. 16:16) indicates no abuse of these institutions prior to that time. This is an argument from silence, and must be held somewhat circumspectly. On the other hand, it would be surprising if such violations had occurred and yet gone without mention by any deuteronomistic redactor of the historical books.

Furthermore, most of the altars and sacrifices to Yahweh specifically identified as apart from the central sanctuary were for special occasions, not at all precluded by Deuteronomy 12:5. The fact that these were seen as compatible with Deuteronomy 12:5 and the whole centralization motif in Deuteronomy, is apparent again from the fact that none of these sacrifices or altars receive censure from any deuteronomistic redactor of the historical books, whereas sacrifices at the 'high places' during and after Solomon's reign regularly receive such censure. At least one altar, at Gibeon, 'the most important high place' (1 Ki.3:4), where Solomon offered sacrifice early in his reign, is to be regarded as provisional, because of unusual circumstances (separation of ark and tabernacle; impending completion of the Solomonic temple); $c f .1 \mathrm{Ki}$. 3:2, which tells us, 'The people. . .were still sacrificing at the high places, because a temple had not yet been built for the Name of the Lord'. Circumstances which were special because of angelic appearances, theophany, or occasions of battle where God's judgment had become apparent, etc., or times of covenant renewal-none of these

${ }^{33} 2 \mathrm{Ch}$. 30:1ff may give the impression that the Passover and the Feast of Unleavened Bread had been celebrated indiscriminately throughout Israel and Judah. But another interpretation might be that they had been generally neglected. Cf. 2 Ch. 30:5, it (the Passover) had not been celebrated in large numbers according to what was written'. Cf. R.B. Dillard, 2 Chronicles (Waco, Word Books 1987) 244. 
are precluded by Deuteronomy 12:5. Such sacrifices could not have been offered at the tabernacle, because they were occasioned by circumstances-theophanies, battles, etc.inevitably removed from that sanctuary.

There were apparently some Yahweh altars, for sacrifice at the 'high places', which are recognized as violations of the Deuteronomic standard (1 Ki. 3:2.3; 22:43; 2 Ki. 12:3; $14: 4 ; 15: 4.35 ; 16: 4 ; 2$ Ch. 30:14). Significantly, these come under rebuke precisely when the prospect $(1 \mathrm{Ki} .3: 2,3)$ or the reality $(1$ Ki. 22:43, etc.) of a central sanctuary (Solomonic temple) comes into view. It appears to have been recognized-even by any putative deuteronomistic redactor-that exceptions had to be made during the hiatus between the time when the ark and tabernacle were separated, and the time when the ark was brought into the temple.

Finally, our survey clears up the sort of misunderstanding which is common regarding the supposed conflict between many sacrifices and altars reported in the historical books and the outlook of the 'Deuteronomist'. For instance, Moshe Weinfeld thinks that the altars and sacrifices mentioned in Judges 6:26 (Gideon's altar in honour of Yahweh's manifestation in Ophrah) and 13:19 (Manoah's offering at the ascent of the angel of Yahweh) would have been excluded by the Deuteronomist, and concludes: 'The sin of the high places, then, is an invention of the Deuteronomist: prior to him it was entirely unknown in Israel.'34 Both of these are cases of theophany or angelic appearance, involving sacrifice that could not have been made at a central sanctuary, and not at all in contradiction to the deuteronomic law.

The biblical picture from Joshua through Kings thus appears to be one of fluctuating obedience to the deuteronomic command. There was movement toward a more complete fulfilment in the Solomonic temple. But violations, as noted, persisted throughout the monarchy. As Wenham has observed, complete centralization did not occur until after the Exile. 35

${ }^{34} \mathrm{M}$. Weinfeld, 'Cult Centralization in Israel in Light of a NeoBabylonian Analogy', JNES 23 (1964) 202-12 (esp. 203); cf. Halpern, op. cit., 22. One wonders why the putative Deuteronomist made no critical comment on these earlier supposed violations of the deuteronomic law.

35Wenham, op. cit., 109. 
The fact that Deuteronomy 12:5 was not perfectly fulfilled before Solomon's temple, or even after, does not require the conclusion that it was written as part of a reform effort in Josiah's day, any more than Israel's persistent syncretism, from the wilderness wanderings onward, necessitates a seventh century date for Deuteronomy's polemic against idolatry. 36

The overall picture presented in Deuteronomy itself is one of anticipation. The Lord will choose a place from among the tribes of Israel 'to place his Name there'.

Where is the place in which Yahweh first chooses to place his Name? The biblical evidence points to Shiloh. Jeremiah states this clearly, and employs the 'Name' phraseology: 'Go now to the place in Shiloh where I first made a dwelling for my Name' (Je. 7:12-15).

Jeremiah alludes to the establishment of the tabernacle at Shiloh, as recorded in the book of Joshua (Jos. 18:1,10). There it stayed for some time. It is probably mentioned as being there after Samson's death (the Danites took Micah's graven image and set it up in Shiloh, where it remained 'as long as the house of God [sc. 'the tabernacle?'] was at Shiloh' (Jdg. 18:31). ${ }^{37}$ Some think it was replaced by a structure with 'doorposts' and 'doors', referred to as the 'temple of Yahweh' at Shiloh during the days of Eli, who served there (1 Sa. 1:3.9ff), 38 although it is conceivable that this structure was simply the tabernacle, since we read in 1 Samuel 2:22 how Eli's sons, who were ministering at Shiloh (14) 'slept with women who served at the entrance to the Tent of Meeting' ${ }^{39}$

${ }^{36}$ Israel's penchant for idolatry became obvious enough in the wilderness for the warnings in Deuteronomy to be relevant prior to the conquest.

37It is clear from, e.g., Ps. 27:4-5, that the terms 'the house of Yahweh'

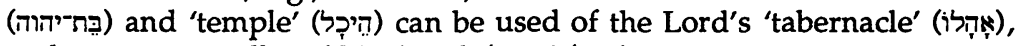
and even, poetically, of his 'booth/tent' (הכ)

${ }^{38}$ E.g., Thompson, op. cit., 36.

${ }^{39}$ The Hebrew terms (מיוּז היכַל יהוה ('doorpost of the temple of Yahweh', 1 Sa. 1:9), and רִּרז ('doors', 1 Sa. 3:15), are not elsewhere used of tents in the OT. However, Keil \& Delitzsch, op. cit., II, 23, suggest that in 1 Sa. 1:9 the מir is probably a porch, which had been placed before the curtain that formed the entrance into the holy place, when the tabernacle was erected permanently at Shiloh'. They further suggest (50-1) that the 'doors' are there because, once the tabernacle was 
The biblical record makes a distinction between the tabernacle, or 'house', or 'temple' of Yahweh during this period, and the ark of Yahweh. The ark was temporarily captured by the Philistines during Eli's judgeship. The Philistines did not find the ark to their liking, and returned it to Israel. It was placed in the house of Abinadab in KiriathJearim (1 Sa. 7:1,2), where it remained until David had it brought to Jerusalem, where he pitched a tent for it (2 Sa. 6:2ff/1 Ch. 15:1ff). This tent, built perhaps after the pattern of the original tabernacle, is subsequently referred to as the 'house of the Lord' at Jerusalem (2 Sa. 12:20; cf. 15:25). The ark remained in the Davidic tent until Solomon removed it to the newly constructed temple ( $1 \mathrm{Ki}$. 8:1ff; $2 \mathrm{Ch}$. 5:2ff).

The place where Yahweh finally places his Name, or causes it to dwell, is this same temple in Jerusalem. Solomon declares it so at the temple dedication. First, he reviews the historical background:

Praise be to the Lord, the God of Israel, who with his own hand has fulfilled what he promised with his own mouth to my father David. For he said, "Since the day I brought my people Israel out of Egypt, I have not chosen a city in any tribe of Israel to have a temple built for my Name to be there, but I have chosen David to rule my people Israel" (1 Ki. 8:15-16).

Solomon alludes here to Yahweh's original dynastic promise to David, in the context of which the Lord said to David:

Are you the one to build me a house to dwell in? I have not dwelt in a house from the day I brought the Israelites up out of Egypt to this day. I have been moving from place to place with a tent as my dwelling. Wherever I have moved with all the Israelites, did I ever say to any of their rulers whom I commanded to shepherd my people Israel, "Why have you not built me a house of cedar?" (2 Sa. 7:5-7).

The 'movings about' mentioned here are clearly not just the wilderness wanderings, but also subsequent movings under 'rulers' who came after Moses. ${ }^{40}$ This would include the

permanently pitched at Shiloh, buildings for the Levites were built around it, replacing the original tent-like enclosure around the court, and 'doors' replaced the curtains at the entrance.

40In the parallel passage, $1 \mathrm{Ch}$. 17:4-6, we read that Yahweh has moved

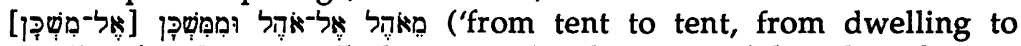
dwelling'). This may allude to David's placement of the ark in the tent at Jerusalem; or it may be translated, 'from one tent site to another, 
removal of the tabernacle from Shiloh to Gibeon, for in 1 Chronicles 16:37ff David left Asaph and his associates to minister before before the ark of the covenant in the tent at Jerusalem, to 'make petition, to give thanks, and to praise the Lord,' (1 Ch. 16:4), and Zadok the priest and his fellow priests before the tabernacle at the high place at Gibeon, to offer daily burnt offerings according to the Law of Moses.41 The tabernacle apparently remained at Gibeon until Solomon's day, since 1 Chronicles 1:3 tells us that 'Solomon and the whole assembly went to the high place at Gibeon, for God's Tent of Meeting was there, which Moses the Lord's servant had made in the desert'. Solomon brings the tabernacle from Gibeon to Jerusalem at the same time that he brings the ark from the Davidic tent to install it in the newly constructed temple (1 Ki. 8:1-4; 2 Ch. 5:5). Perhaps, as Keil and Delitzsch suggest, the tabernacle was brought to Jerusalem as a 'holy relic' .42

But to return to Solomon and the temple dedication. The 'Name' phraseology implies that Yahweh will be present where his Name is, and Solomon prays that Yahweh will in fact be accessible at the temple: 'May your eyes be open toward this temple night and day, this place of which you said, " $M y$ Name shall be there", so that you will hear the prayer your servant prays toward this place' (1 Ki. 8:29).

The Lord appears to Solomon soon after and assures him, 'I have consecrated this temple, which you have built, by putting

from one dwelling place to another', as does NIV. M. Noth, The History of Israel (New York, Harper \& Row 19602) 94-7, has argued that the chosen 'place' was variously Shechem (Jos. 24:1), Bethel (Jdg. 20:18,26,27), Gilgal (on the basis of Jos. 3-4!), and Shiloh (Jdg. 18:31; 1 Sa. 1:3.21, 4:3.4). As Thompson notes, however, such references, except for Shiloh, are questionable, indicating merely covenant renewal ceremonies, and not at all necessitating the presence of the tabernacle or Deuteronomy's sense of the chosen place (Thompson, op. cit., $162 \mathrm{n}$. 3). For a fuller discussion and refutation of the claims of Shechem, Bethel and Gilgal, cf. Wenham, op. cit., 105-8, 114-5.

${ }^{41}$ Abiathar, the high priest, would have overseen sacrificial worship in the Jerusalem sanctuary; he is not mentioned in $1 \mathrm{Ch}$. 16:4-5 because the emphasis there is on the musical ministry of the Levites.

42Keil \& Delitzsch, op. cit., III, 324. 
my Name there forever. My eyes and heart will always be there' (1 Ki. 9:3).43

Subsequent uses of the 'Name' phraseology are in contexts of judgment or indictment: in Ahijah's donation of the ten tribes to Jeroboam (1 Ki. 11:36), the record of Rehoboam's reign (1 Ki. 14:21), the review of Manasseh's sins (2 Ki. 21:4.7), and the Lord's ultimate rejection of his city and temple, in spite of Josiah's reforms: 'I will remove Judah also from my presence as I removed Israel, and I will reject Jerusalem, the city I chose, and this temple, about which I said, "There shall my Name be"" (2 Ki. 23:27).

A survey of the 'Name' phraseology shows its significance in the Old Testament record. It is first applied to the Lord's dwelling in Deuteronomy 12:5, in the form of a promise. It is last applied in 2 Kings 23:27, in the form of a curse. It can be applied to the tabernacle at Shiloh (Je. 7:12), or to the Jerusalem temple (1 Ki. 8:16ff).

The shift in application seems reasonable. When the circumstances change, the phrase changes also. Thus, in Moses' day, the phrase took the form of an implicit promise: 'you are to seek the place the Lord your God will choose from among all your tribes to put his Name there for his dwelling' (Dt. 12:5). On the other hand, in Solomon's day, the phrase applied to the place which had now been chosen: 'I have consecrated this temple. . .by putting my Name there forever' (1 Ki. 9:3). Subsequently in Judah's history, the phrase is applied again and again to Jerusalem and the temple, until the Lord rejects 'Jerusalem, the city I chose, and this temple, about which I said, "There shall my Name be"' (2 Ki. 23:27). The application of a traditional phrase to changing circumstances over centuries is just what we would expect in the Ancient Near East, which is well known for its literary conservatism.

\section{The Challenge}

The reasonableness of the biblical record has been subject to challenge, however, for quite some time. In 1833, de Wette argued that the provision in Deuteronomy 12 was an example

${ }^{43}$ The promise is not 'forever', in our sense of the word. Rather, it is of indefinite duration: i.e., as long as Solomon and his sons are faithful to Yahweh. If they turn away from him, however, he will 'reject this temple I have consecrated for my Name' (1 Kgs. 9:7). Cf. Je. 7:4ff. 
of 'Legislation, which indicates later circumstances, namely the temple in Jerusalem'.44 De Wette's argument was just part of a larger thesis, first advanced in his Dissertatio Critica in 1805, that an author different from and later than Moses wrote the book of Deuteronomy.

The question of Mosaic authorship can only be addressed in the broadest way in this paper. But the handling of the 'Name' phraseology by scholars from de Wette onwards deserves special attention.

The general trend has been, like de Wette, to see Deuteronomy 12:5 and subsequent 'Name' references in that book as veiled allusions to the Jerusalem temple. These allusions were made by the Deuteronomist(s), who began their work not long before the time of Josiah and 'were still at work after the fall of Judah'.45 They were made to prepare the ground for the claim, made by the deuteronomistic historian (= Deuteronomist), that Jerusalem was the place which Yahweh chose for his dwelling. More specifically, he had chosen the Jerusalem temple. Consequently, all worship must be centralized there, and worship or sacrifice elsewhere was illegitimate. The insistence on centralization of worship in Jerusalem was part of the larger deuteronomic reform movement, which enlisted the support of Josiah and which had as its advocate the prophet Jeremiah. Josiah sought reform after reading the rediscovered book of Deuteronomy, which had been found by the high priest Hilkiah during the renovation of the temple ( $2 \mathrm{Ki}$. 22:3ff). Deuteronomy had been written and deposited in the temple only shortly before its discovery. It was a 'pia fraus' perpetrated by the reform party. Jeremiah was attached to this party, as the presence of deuteronomic phraseology in his book (and especially in the prose) makes clear. Bishop Colenso even went so far as to

44W.M.L. de Wette, Lehrbuch der historisch-kritischen Einleitung in die kanonischen und apokryphischen Bücher des Alten Testaments (Berlin, G. Reimer 1833) 201.

${ }^{45} \mathrm{M}$. Weinfeld, Deuteronomy and the Deuteronomic School (Oxford, Clarendon 1972) 9. For arguments favoring two Deuteronomists, a preexilic (Dtr ${ }^{1}$ ) and an exilic (Dtr $\left.{ }^{2}\right), c f$. F.M. Cross, Canaanite Myth and Hebrew Epic (Cambridge, Harvard 1973) 274-89; R.D. Nelson, The Double Redaction of the Deuteronomistic History (Univ. of Sheffield 1981); R. Clifford, S.J., Deuteronomy (Wilmington, Michael Glazier 1982). 
argue that Jeremiah wrote Deuteronomy. When he was still young and could command no hearing as a prophet, Colenso argued, Jeremiah penned Deuteronomy as an instrument of reform, and passed it off under the name of Moses, which he knew would command a hearing. ${ }^{46}$

Subsequent scholars, such as Driver, parted company with Colenso at this point.47 Yet many have held that the 'Name' phraseology in Deuteronomy 12:5 and following was the product of the Deuteronomist, who was active around the seventh century BC But a more careful study of this phrase and its usage, against its Ancient Near Eastern background, commends to us its antiquity, and casts doubt on the claims made regarding it.

\section{Evidence from the Ancient Near East}

The command in Deuteronomy 12:5 is that 'you are to seek the place the Lord your God will choose from among all your tribes to put his Name there for his dwelling'. Two features of this phrase appear to be very ancient: the concept of the 'Name', and the idea that one can 'place one's name' somewhereindicative of effective presence.

As to the former some have regarded this as a relatively advanced idea: that the 'Name' should stand for the essential character of the one named, and should even be used to refer to that one. But we have evidence from the Ancient Near East which testifies to the antiquity of this concept. In Sumerian, as Wolkstein points out, 'With the act of naming. . .what is inside becomes manifest. . .In Sumerian mu-lugal means "man's name" and also "life-giving properties"'.48 In other words, the identification of 'Name' and 'essential character/nature' is very early in the Ancient Near East-third

46J.W. Colenso, 'The Book Found in the Temple', Lecture XI in Lectures on the Pentateuch and the Moabite Stone (London, Longmans, Green \& Co 1873) 143-54; cf. 'Jeremiah and the Deuteronomist', Lecture XII, 157-67; cf., idem, The Pentateuch and Book of Joshua Critically Examined: Pt. III, The Book of Deuteronomy (London, Longmans, Green \& Co 1875) 192-202.

47S.R. Driver, Deuteronomy xli-xlviii; Introduction to the Literature of the Old Testament 9 [hereafter, ILOT] (Edinburgh, T. \& T. Clark 1913) 275-77.

${ }^{48}$ D. Wolkstein and S.N. Kramer, Inanna: Queen of Heaven and Earth (New York, Harper \& Row 1983) 138-9. 
millennium, as the Sumerian documents attest. The concept of the 'name' as the essential character of deity is also very ancient. In Ugarit, Astarte is described as the 'Name' of Baalthat is, as Gibson notes, 'a title designed to describe her as a manifestation of Baal, whose consort she in fact is'.49 In other words, Astarte is the 'Name', or in some sense the manifest character, of Baal. Moreover, when on one occasion Astarte rebukes Baal, she does so, as Gibson further notes,

Interestingly using the title, "the Name", an example of a religious fastidiousness usually thought in biblical circles to be a mark of advanced theological awareness and therefore of late development. 50

We have here yet another case of a concept which some scholars have regarded as 'advanced', yet which actually appears very ancient in the world of the Bible. Another example might be the deuteronomic concern for 'the widow and the orphan', which Moshe Weinfeld regards as a mark of the advanced humanism of the Deuteronomist in the seventh century $\mathrm{BC}, 51$ but which also appears as an attribute of the wise king Daniel in Ugaritic poetry (14th-12th century BC), 52 and as a quality of Hammurapi of Babylon in his famous Code (18th century BC). 53

The second concept, that of 'placing one's name' somewhere, in the sense of effective presence, is also quite

${ }^{49}$ J.C.L. Gibson, Canaanite Myths and Legends (Edinburgh, T. \& T. Clark 1977) 4, n. 6. Cf. A. Caquot, M. Sznycer, and A. Herdner, Textes Ougaritiques, I, Mythes et Légendes (Paris, Editions du Cerf 1974) 93-4. The same title appears much later, 5th Century BC in Phoenician (Eshmunazar Inscription); cf. H. Donner \& W. Rollig, Kanaanaische und Aramaische Inschriften, II (Wiesbaden, Harrassowitz 1973) 19-23, and the fascinating parallel whereby the goddess Tanit is called the presence of Baal' (פן בעל) in Carthaginian inscriptions, 96.

50 Ibid., 6., n. 1. For the syntax (bsm tg $\underline{c} m, 2$, iv, 28), cf. R.E. Whitaker, $A$ Concordance of the Ugaritic Literature (Cambridge, Harvard 1972) 167, and Cyrus Gordon, Ugaritic Textbook 3 (Rome, Pontifical Biblical Institute 1965) 381. The verb, $g \underline{C}$, in the transitive sense of 'rebuke', uses the preposition, $\underline{b}$, to achieve the accusative in Ugaritic.

51Weinfeld, 290.

52 Aqhat (17 $\vee 7-8$ ), 'At the threshing floor he judges the cause of the widow, he tries the case of the orphan' (bgrn ydn dn 'almnt ytpt tpt ytm).

${ }^{53} \mathrm{CH}$ XXIV.R.60ff. 
ancient. The phrase, 'to place one's name', is used in Akkadian to describe a king's placement of a stele with his name inscribed on it. As de Vaux ${ }^{54}$ and Wenham ${ }^{55}$ have noted, this act indicates his possession of the place. It also indicates his effective presence there. It appears in this sense in the Amarna correspondence, in which the Pharaoh 'has established his name in the country of Jerusalem for ever'.56 The phrase means simply, that Pharaoh is so intimately involved as suzerain over Jerusalem, that any affront to Jerusalem is also an affront to him, and on this basis the king of Jerusalem appeals to Pharaoh for help against those who are harassing the city. In other words, because the 'name' of Pharaoh, the suzerain, is in Jerusalem, Pharaoh must protect it. The Amarna evidence curiously anticipates the idea-denounced by Jeremiah-that because the 'Name' of Yahweh, the Suzerain, is in the Jerusalem temple, Yahweh must protect Jerusalem against any foe (Je. 7:4ff).

It appears, then, that both of these key concepts-the 'Name' and the placing of the 'Name' in Deuteronomy 12:5 (and subsequently in Dt. and 1 and $2 \mathrm{Ki}$.)-are quite ancient. Both appear in the second millennium-Mosaic date and earlier-well before the putative Deuteronomist of the seventh century $\mathrm{BC}$.

The issue in Deuteronomy is not just the Ancient Near Eastern background of the phrase. For the phrase might have an ancient background, yet still stem from the seventh century. The issue, rather, is that the same phrase appears subsequently in the books of Kings, where it is applied specifically to Jerusalem and the Solomonic temple. Because it appears in the later books, scholars argue, it makes sense to see the phraseology in Deuteronomy as a later development, and a veiled allusion to the Solomonic temple, dating from Josiah's day.

Evidence of phrase usage in the Ancient Near East would suggest otherwise. A relevant example comes from Assyria. For centuries, Assyrian kings boasted in their annals and other inscriptions that they brought back booty from their

54R. de Vaux, 'Bulletin', RB 63 (1966) 449.

55Wenham, op. cit., 113-4.

56J.A. Knudtzon, Die El-Amarna Tafeln, I. (Leipzig, J.C. Hinrichs 1915) 287, lines 60-1. 
military campaigns, either to their city, Ashur, or to their land, Ashur. ${ }^{77}$ But this stock phrase, e.g., 'I brought back their booty, their prisoners, and their idols/statues to my city Ashur', underwent change through time, as the circumstances changed. Morton Cogan remarks:

MA [Middle-Assyrian] texts specify that the statues were brought ana äliya Ašsur, "to my city Ashur". This specification holds true at least down to the reign of Tukulti-Ninurta II, at which time Nineveh is first mentioned. From the middle of the ninth century onward, the earlier phrase ana älìya Ašsuris gradually replaced by ana (qereb) mät Asšur, "into (the midst of) Assyria", which becomes the standard term in all NA [Neo-Assyrian] inscriptions. Even though no NA text explicitly states the place within Assyria to which the statues were transferred, the change in language may be significant. Had the city of Ashur continued to be the sole location, we would be at a loss to explain the introduction of new and less specific terminology. . . Throughout the late NA period spoils of war were divided up among various centers-the capital and its temples, the army, and outlying provincial districts. The founding of new cities required this kind of endowment. The possibility, therefore, suggests itself that with the expansion of the empire and official recognition of new capitals and sacred precincts, provision was made for the reception of statues, along with other booty, in many locations throughout Assyria and its provinces. 58

In other words, the original phrase, 'I brought back $X$ to my city, Ashur', changed, and became less specific: 'I brought back X to my land, Ashur/the land Ashur (Assyria)'. This change in phraseology took place because the circumstances had changed: now the booty not only came to the capital, but, as the empire expanded, was distributed to various places in it (cities and temples) as there was need.

This clear example of a stock phrase which undergoes change because of changing circumstances is relevant to the 'Name' phraseology in Deuteronomy and Kings. For it might be argued that the phrase first appeared on the lips of Moses with an indefinite reference, before the Conquest: 'the place the Lord your God will choose from among all your tribes to put his Name there for his dwelling'. Subsequently, when

${ }^{57}$ Cf. CAD, 1, 12 (abalu, 6').

${ }^{58} \mathrm{M}$. Cogan, Imperialism and Religion: Assyria, Judah and Israel in the Eighth and Seventh Centuries B.C.E. (Missoula, Scholars Press 1974) 25-6. 
Jerusalem - and specifically its temple-emerged as the chosen place, the phrase likewise became more specific, and changed to, e.g., 'this temple and.. .Jerusalem, which I have chosen out of all the tribes of Israel, [to put] my Name forever' (2 Ki. 21:7).

In the historical books of the Old Testament, this deuteronomic phraseology is applied only to Jerusalem and its temple. This reflects the fact, or the emphasis, that the Jerusalem temple was ultimately the place in which Yahweh chose to place his name. Jeremiah, however, also uses the deuteronomic phrasing, and applies it to Shiloh, as we have seen: 'the place in Shiloh where I first made a dwelling for my Name' (Je. 7:12). The change of application of the phrase from the general statement of Deuteronomy 12:5 to Shiloh in Jeremiah, and to the Jerusalem temple in 1 Kings $8 \mathrm{ff}$, is perfectly consistent with the phenomenon observed in Assyrian tradition, where the application of a stock phrase changes with circumstances.

Jeremiah's use of the phrase may also reflect another reality. Since the time of de Wette, scholars have generally believed that the document which Hilkiah discovered in the temple, and which caused Josiah to tear his robes and institute reform, was Deuteronomy (or at least a substantial portion of it) with its powerful polemic against idolatry. ${ }^{59}$ If the 'book of the Law' Hilkiah discovered was Deuteronomy, then Jeremiah's use of deuteronomic phraseology would make perfect sense. 60 As Rowley has remarked in another context:

It is sometimes claimed that Jeremiah was so original a person that it is antecedently improbable that he was a copier from Deuteronomy. This purely a priori argument is of little weight. The most original English writer might be forgiven for referring to Habeas Corpus, and Jeremiah's originality is not called in question if he shows some knowledge of the provisions of the newly found

${ }^{59} \mathrm{Cf}$. Driver, ILOT, 86-7; O. Eissfeldt, The Old Testament: An Introduction E.T. P. Ackroyd (Oxford, Basil Blackwell 1965) 171.

${ }^{60}$ Some, like J. Gray, I \& II Kings 2 (Philadelphia, Westminster 1970) 716, have objected that Dt. as we have it is too long to have been read in one day, as was the 'Book of the Law' to Josiah. In fact, however, it takes only between five and ten minutes to read an average chapter of Dt. It seems obvious from this that even the whole book as we have it might be read in a day, with pauses for rest or reflection. The argument that the time factor militates against the rediscovered book's being as large as $D t$. is, therefore, fallacious. 
law-book. . .The vocabulary and style of Jeremiah were, like every other author's, in large measure those of his age, and a book which was believed to be a divinely given law might be expected to exercise a profound influence on the style of writers in the age when it became known. 61

It should come as no surprise, therefore, that Jeremiah uses the phraseology of Deuteronomy, or that he applies it to the tabernacle at Shiloh. He simply employs phraseology of theological significance, taken from a document which had been deposited in the temple some time before, and rediscovered in his day.

There is good evidence from the Ancient Near East for this practice of depositing written materials in temples, as well as evidence for their rediscovery, and the re-use of stock phraseology stimulated by that rediscovery. For example, the Assyrian king, Shamshi-Adad I (1814-1782 BC), deposited an inscription in the temple of his god, Enlil. The inscription contained an account of his military exploits and the good state of the economy under his rule, as well as an account of work on the temple. He boasts in the inscription that he 'placed [his] great name in the land of Laban [Lebanon] at the coast of the Great Sea (Mediterranean Sea)'.62 Near the end of the inscription comes an injunction to any future king who renovates the temple: When the temple becomes delapidated and any of the kings, my offspring, renovates the temple, may he anoint my clay inscriptions and steles with oil, offer sacrifice, and return them to their place' .63

${ }^{61}$ H.H. Rowley, 'The Prophet Jeremiah and the Book of Deuteronomy', in Studies in Old Testament Prophecy, H.H. Rowley (ed.) (Edinburgh, T. \& T. Clark 1950) 170.

${ }^{62}$ E. Ebeling, B. Meissner, \& E.F. Weidner, Die Inschriften der Altassyrischen Könige [hereafter IAK] (Leipzig, Quelle \& Meyer 1926) 24-5 (VIII.1.Rs.4.12-18); A.K. Grayson, Assyrian Royal Inscriptions, I (Wiesbaden, Harrassowitz 1972) 19-21. As Grayson notes, the allusion is probably to a stele, with the king's name, sent to the region, though without military conquest: 'In view of the presence of important Amorite states in Syria at this time, a military conquest of this region by Shamshi-Adad is out of the question' (21, n. 65). The phrasing, however, still attests the presence of a 'name' ideology (the whole point of the king's boast!) -and at a very early date.

63IAK, 24-25 (VIII, 1.Rs.4.19-5.7); Grayson, op. cit., 21. 
Generations of kings after Shamshi-Adad I make no mention of the great king's inscription. But during the reign of Arik-din-ili (1319-1308 BC), when that king renovated the Shamash temple, we find again in his inscription the old phraseology of Shamshi-Adad I:

For the days to come: May a future prince, when this temple becomes dilapidated, and he renovates it,-may he anoint my steles with oil, bring a sacrifice, and return them to their place. Shamash will then hear his prayers. 64

Borger remarks that this inscription contains other elements that only appeared previously in the Shamshi-Adad inscription, which suggests that Arik-din-ili discovered the earlier king's inscription and adopted its formulaic phrasing for his own.65 We note, too, the addition of a blessing, that 'Shamash will then hear his prayers'. This is a good example of the expansion and modification of stock-phraseology over centuries of tradition, just as we find in the adaptation of Deuteronomy 12:5 and other phrases from Deuteronomy in the books of Kings. 66

Subsequently, the king Adad-Nirari I (1307-1275 BC) employs the same phraseology, in an inscription commemorating the renovation of a city wall: 'For days to come: May a future prince, when that wall becomes old and dilapidated, renovate it. May he return my inscribed name and my steles to their place. Ashur will then hear his prayers' 67 The phrasing is obviously modelled on that of his predecessor kings, as Borger notes. 68

${ }^{64} I A K$, 50-51 (XIX, 1.48-64); Grayson, op. cit., 54.

${ }^{65} \mathrm{R}$. Borger, op. cit., 1 (Leiden, Brill 1961) 30-1.

66E.g., the development from the general promise of a chosen king (בּ

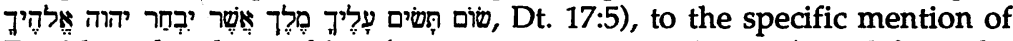

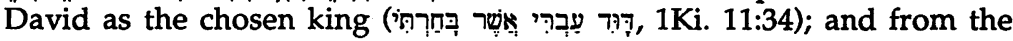

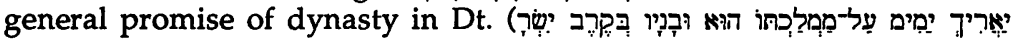

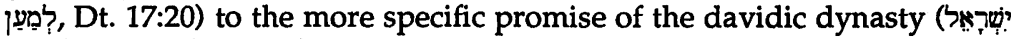

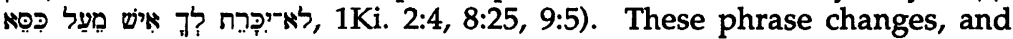
others cited by Weinfeld, 4ff. (and cf. his 'Appendix A', 320-65), illustrate well the sort of changes also found in Assyrian royal tradition over many centuries. We need not confine them to a period of 150 years (from c. 650 to $500 \mathrm{BC}$ ) for their origin and development, as he does.

67IAK, 86-87 (XX, 9.Rs.7-12); Grayson, 65.

68Borger, op. cit., 44. 
Finally, Shalmaneser I (1274-1245 BC), upon renovation of the Ashur temple, remarks:

The steles of the previous kings I anointed with oil, offered a sacrifice, and returned them to their place. For days to come: May a future prince, when this temple grows old and dilapidated, hear of the accomplishments of my might and proclaim the renown of my power. As I have returned the steles of the previous kings to their place, so may he anoint my steles with oil, offer a sacrifice, and return them to their place. Ashur and Ninlil will then hear his prayers. 69

As Borger notes, 70 Shalmaneser deliberately responds to the injunctions of the earlier kings, by declaring that he has performed the required ritual. Consequently, his own inscriptions deserve the same treatment from 'any future prince'.71

The evidence from ancient Assyria makes it quite clear that one king, of very early date, could use phraseology of theological significance in an inscription to be deposited in a temple, and that subsequent kings, upon rediscovery of that document, could employ its phraseology in their own inscriptions, which they then deposited in their renovated temples. 72

The bearing of all this on Deuteronomy is obvious. It gives tangible Ancient Near Eastern precedent for what is reported in 2 Kings 22 . The scenario presented there is that the high priest Hilkiah discovered the previously deposited Book of the Law' during the renovation of the temple; and, once the book had been found, subsequent writers employed its theology and phraseology in their own work, e.g., Jeremiah, the redactor(s) of 1 and 2 Kings.

Interestingly enough, the dates of the Assyrian inscriptions also offer a parallel to the deuteronomic material.

${ }^{69} I A K, 124-5$ (XXI, 1.4.35-Lk.Rd.4); Grayson, op. cit., 84-5.

${ }^{70}$ That ritual first appears in the inscriptions of Shamshi-Adad I; and Shalmaneser I notes that Shamshi-Adad I had rebuilt this same Ashur temple some 580 years before. Perhaps here, too, the earlier king's inscriptions carried the same stock phrasing. Cf. Grayson, op. cit., 84.

${ }^{71}$ Borger, op. cit., $49 \mathrm{ff}$.

72For another example, cf. A.R. Millard, 'Fragments of Historical Texts from Nineveh: Middle Assyrian and Later Kings', IRAQ 33 Pt 2 (1970), 168-9: an Ashur-bel-kala (1074-1057 BC) text, with which historians of Shalmaneser III (858-824 BC) were apparently acquainted and drew upon for phrasing. 
The span from Shamshi-Adad I (1814-1782 BC) to Arik-din-ili $(1319-1308 \mathrm{BC})$ is about 500 years. After the discovery of the original ancient inscription, the phraseology is picked up and employed through the reigns of Arik-din-ili, Adad-Nirari I (1307-1275 BC), and Shalmaneser I (1274-1245 BC)—in other words, over a period of from 34 to 74 years. By comparison, the span from the dedication of Solomon's temple (the earliest time at which the Law Book might have been deposited) to its discovery under Josiah would be some 331 years (from $c$. 952$621 \mathrm{BC}) .73$ The period during which deuteronomic phraseology then appeared would be some 34-plus years (621-587 BC or later), depending upon one's dating of the redaction of the books of Kings. Comparative dates are given just as an illustration of what is possible in the chronology of phraseological development in the ancient world. However, the overall parallel between the Assyrian evidence and the biblical picture is striking. ${ }^{74}$

Modern archaeology has provided us with an abundance of materials for the conduct of Old Testament scholarship. One important area for further research is that of phraseology, both in the Bible and in the Ancient Near East. In this paper we have tried in a small way to indicate what value such a study might have. We suggest that further study of Ancient Near Eastern phraseology in tradition may strongly support the traditional view of the central sanctuary issue in the Old Testament, and even of the Mosaic authorship of Deuteronomy.

${ }^{73} \mathrm{Cf}$. J. Bright, A History of Israel 2 (Philadelphia, Westminster 1975) 214.

${ }^{74} \mathrm{Cf}$. a similar case of Egyptian phraseology in tradition, in K.A. Kitchen, 'Ancient Orient, "Deuteronomism", and the Old Testament', New Perspectives on the Old Testament, J.B. Payne (ē.) (Waco, Word 1970) 8. 